\title{
APPLICATION OF 2D HETERONUCLEAR SHIFT CORRELATIONS TO THE DETERMINATION OF COUPLING SIGNS IN BIS(TRIMETHYLTIN) SULFIDE, SELENIDE, TELLURIDE, IN TRIMETHYLTIN METHYLSELENIDE AND IN BIS(TRIMETHYLSILYL) SELENIDE
}

\author{
Bernd Wrackmeyer*, Kurt Bauer, Gerald Kehr and Udo Dörfler
}

Laboratorium für Anorganische Chemie der Universität Bayreuth, D-95440 Bayreuth, Germany

\begin{abstract}
Signs of various coupling constants over one-, two-, three and four bonds have been determined by using 2D heteronuclear shift correlations for trimethyltin chalcogenides $\left(\mathrm{Me}_{3} \mathrm{Sn}\right)_{2} \mathrm{E}$ [E = S (1), Se (2), Te (4)], Me ${ }_{3} \mathrm{SnSeMe}$ (3), and bis(trimethylsilyl)selenide (2(Si)) for comparison. The signs of the geminal, vicinal and other long-range coupling constants have been determined for the first time. All geminal coupling constants ${ }^{2} \mathrm{~J}\left({ }^{119} \mathrm{Sn}^{117} \mathrm{Sn}\right)$ have a negative sign and ${ }^{2} \mathrm{~J}\left({ }^{119} \mathrm{Sn}^{13} \mathrm{C}\right)$ in 3 is positive $\left({ }^{2} \mathrm{~K}\left({ }^{119} \mathrm{Sn}^{13} \mathrm{C}\right)(0)\right.$. The 2D heteronuclear shift correlations enable the determination of small long-range coupling constants (e.g. ${ }^{3} \mathrm{~J}\left(\mathrm{E}^{1} \mathrm{H}\right)\left(\mathrm{E}={ }^{77} \mathrm{Se}{ }^{125} \mathrm{Te}\right)$ or $\left.{ }^{4} \mathrm{~J}\left({ }^{117 / 119} \mathrm{Sn} \mathrm{n}^{1} \mathrm{H}\right)\right)$ which are normally not resolved in $1 \mathrm{D}{ }^{9} \mathrm{H}$ NMR spectra. These data can be used to optimize conditions for recording ${ }^{77} \mathrm{Se}$ or ${ }^{125} \mathrm{Te}$ NMR spectra via ${ }^{1} \mathrm{H}$ polarization transfer techniques.
\end{abstract}

\section{INTRODUCTION}

${ }^{119}$ Sn NMR parameters are exploited in many ways for the characterization of pure compounds, for the analysis of mixtures, and for studying the dynamic behaviour of compounds with regard to intra- and/or intermolecular exchange processes, to name only a few applications ${ }^{1}$. By making use of the ever-increasing performance of NMR spectrometers a large data set, in particular of coupling constants involving ${ }^{117 / 119} \mathrm{Sn}$, is becoming available. A meaningful discussion of these data requires the information on the sign of the coupling, preferably on the absolute sign. For numerous different nuclei $X$ the signs of one-bond coupling constants ${ }^{1} \mathrm{~J}\left({ }^{199} \mathrm{Sn} X\right)$ have already been determined", In the case of geminal coupling constants, ${ }^{2} J\left({ }^{119} S n X\right)$, or ${ }^{n} J\left({ }^{119} S n X\right)$ with $n \geq 3$, the situation is less satisfactory, since coupling signs for a greater number of derivatives are known ${ }^{1}$ only for $n=$ 2, 3 and $X={ }^{1} \mathrm{H}$, with a coupling pathway across one and two carbon atoms, respectively. 

in Bis(Trimethyltin) Sulfide, Selenide, Telluride, in Trimethyltin Methylselenide

There are rather few examples of coupling signs known for nuclei $X$ other than proton although a large data set of magnitudes can be found in the literature. Here, we want to report on the determination of signs of various coupling constants in the organotin chalcogenides 1 to 4 . For comparison, the bis(trimethylsilyl)selenide (2 Si) was included.

\begin{tabular}{|cccccc|}
\hline & & & & & \\
$\left(\mathrm{Me}_{3} \mathrm{Sn}\right)_{2} \mathrm{~S}$ & $\left(\mathrm{Me}_{3} \mathrm{Sn}\right)_{2} \mathrm{Se}$ & $\left(\mathrm{Me} \mathrm{Si}_{2} \mathrm{Se}\right.$ & $\mathrm{Me}_{3} \mathrm{Sn}^{\prime} \mathrm{Se}_{M e}$ & $\left(\mathrm{Me} \mathrm{Sn}_{2} \mathrm{Te}\right.$ \\
1 & 2 & $2(\mathrm{Si})$ & 3 & 4 \\
\hline
\end{tabular}

\begin{tabular}{|c|c|c|c|c|}
\hline $\begin{array}{l}\text { Compound } \\
\mathrm{Nr} \text {. }\end{array}$ & $\delta^{13} \mathrm{C}(\mathrm{SnMe})$ & $\delta^{119} \mathrm{Sn}$ & $\delta^{77} \mathrm{Se} / \delta^{125} \mathrm{Te}$ & $\delta^{1} \mathrm{H}$ \\
\hline 1 & $\begin{array}{l}-2.5 \\
{\left[\begin{array}{ll}-353.7 \\
{[}\end{array}\right]} \\
{\left[\begin{array}{l}5.5 \\
\end{array}\right]}\end{array}$ & $\begin{array}{l}+87.1^{[\mathrm{b}]} \\
{[-215.8]}\end{array}$ & $-\quad-$ & $\begin{array}{l}0.31 \\
{[+56.0]} \\
{[+0.7]}\end{array}$ \\
\hline 12 & $\begin{array}{l}-2.3 \\
{[-337.8]} \\
(-6.4)\end{array}$ & $\begin{array}{l}+42.7^{[c]} \\
{[-232.2]} \\
(+1087)\end{array}$ & $\begin{array}{l}-549.9\left({ }^{\pi} \mathrm{Se}\right) \\
{[+1087]}\end{array}$ & \begin{tabular}{|l|}
0.37 \\
{$[+55.7]$} \\
{$[+0.3]$} \\
$(+1.5)$ \\
\end{tabular} \\
\hline $2(\mathrm{Si})$ & $\begin{array}{l}4.7(\mathrm{SiMe}) \\
\langle 52.5\rangle \\
(7.1)\end{array}$ & $\begin{array}{l}+11.2\left({ }^{29} \mathrm{Si}\right) \\
(-109.2)\end{array}$ & $\begin{array}{l}-337.8\left({ }^{7} \mathrm{Se}\right) \\
\langle-109.2\rangle\end{array}$ & $\begin{array}{l}0.36 \\
\langle+7.0\rangle \\
\langle+0.5\rangle \\
(+3.7)\end{array}$ \\
\hline 3 & 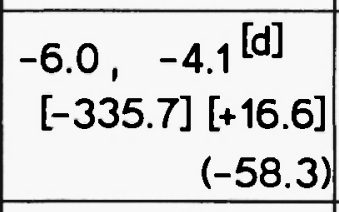 & $\begin{array}{l}+46.0^{[e]} \\
(+1035)\end{array}$ & $\begin{array}{l}-284.7\left({ }^{\pi} \mathrm{Se}\right) \\
{[+1035]}\end{array}$ & $\begin{array}{l}0.52,1.94^{[d]} \\
{[+55.7][-31.2]} \\
(+2.0)(+10.1) \\
\end{array}$ \\
\hline 4 & $\begin{array}{l}-3.4 \\
{[-316.4]}\end{array}$ & $\begin{array}{l}-68.2^{[f]} \\
{[-226.8]} \\
\{-2817\}\end{array}$ & $\begin{array}{l}-1232.1\left(^{125} \mathrm{Te}\right) \\
{[-2817]}\end{array}$ & $\begin{array}{l}0.48 \\
{[+55.0]} \\
{[+1.7]} \\
(-3.0\}\end{array}$ \\
\hline
\end{tabular}

[a] Coupling constants $\mathrm{J}\left({ }^{119} \mathrm{SnX}\right)$ in $\left[\mathrm{J}, \mathrm{J}\left({ }^{77} \mathrm{SeX}\right)\right.$ in ( ) J( $\left.{ }^{125} \mathrm{TeX}\right)$ in \{\} and $\mathrm{J}\left({ }^{29} \mathrm{~S}(\mathrm{X})\right.$ in \langle\rangle (all in $\mathrm{Hz}$ ); note that both $\gamma\left({ }^{119} \mathrm{Sn}\right)<0$ and $\gamma\left({ }^{125} \mathrm{Te}\right)<0$. [b] $\delta^{119} \mathrm{Sn}\left(\mathrm{CDCl}_{3}\right)+93.9^{15}$. - [c] $\delta^{119} \mathrm{Sn}\left(\mathrm{CDCl}_{3}\right)+50.7^{15}$. - [d] Data for SeMe group. - [e] $\delta^{119} \mathrm{Sn}+45.6, \delta^{77} \mathrm{Se}-276.7^{4 \mathrm{~b}}$. - [f] $\delta^{119} \mathrm{Sn}\left(\mathrm{CDCl}_{3}\right)-59.3^{15}$. 


\section{RESULTS AND DISCUSSION}

The ${ }^{13} \mathrm{C}-,{ }^{77} \mathrm{Se},{ }^{119} \mathrm{Sn}$ - and ${ }^{125} \mathrm{Te}$ NMR data of the compounds 1 to 4 are listed in Table 1. The signs of ${ }^{1} \mathrm{~J}\left({ }^{119} \mathrm{SnX}\right)\left(\mathrm{X}={ }^{13} \mathrm{C}^{3},{ }^{77} \mathrm{Se}^{4}\right.$ and $\left.{ }^{125} \mathrm{Te}^{4}\right)$ are in agreement with the literature data where the sign determinations were carried out using 10 heteronuclear double resonance techniques ${ }^{5}$. The magnitudes of ${ }^{1} \mathrm{~J}\left({ }^{119} \mathrm{SnX}\right)$ differ slightly from reported data which may be due to the effect of the solvent, and/or concentration, and/or temperature. So far no signs of couplings ${ }^{2} \mathrm{~J}\left({ }^{119} \mathrm{SnX}\right)\left(X={ }^{13} \mathrm{C},{ }^{117 / 119} \mathrm{Sn}\right)$ across sulfur, selenium or tellurium are known. There are problems in the sign determination even with $2 \mathrm{D}$ heteronuclear shift correlations (HETCOR). Since the absolute sign is of particular interest, "key coupling constants" for which the absolute sign is known (such as ${ }^{1} \mathrm{~J}\left({ }^{13} \mathrm{C}^{1} \mathrm{H}\right.$ ) > $\mathrm{O}^{6}$ or $\left.{ }^{2} \mathrm{~J}^{119} \mathrm{Sn}^{1} \mathrm{H}_{\mathrm{Me}}\right), ?$ ) must be included in one of the comparisons of coupling signs.

There is one approach, proposed recently and applied to $1^{8}$, which appears to be generally valid for many organotin compounds containing two or more tin atoms. This is based on the assumption that there should be long range coupling constants

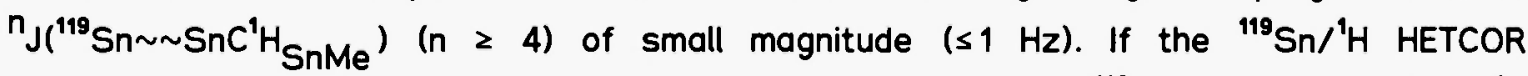
experiment can be based on such small scalar coupling, both ${ }^{119} \mathrm{Sn}$ and the distant ${ }^{1} \mathrm{H}$ are the active nuclei and the ${ }^{117} \mathrm{Sn}$ nucleus in the framework ${ }^{119} \mathrm{Sn \sim} \sim{ }^{117} \mathrm{SnC}{ }^{1} \mathrm{H}_{\mathrm{SnMe}}$ is the passive nucleus. Thus, in the $2 \mathrm{D}$ HETCOR experiment the tilt of the respective cross peaks ${ }^{9}$ enables the comparison of the signs of ${ }^{{ }}{ }^{119}\left({ }^{119} n^{117} \mathrm{Sn}\right)$ and of ${ }^{2} \mathrm{~J}\left({ }^{117} \mathrm{Sn}^{1} \mathrm{H} \mathrm{SnMe}\right)$. Since the latter is known to be positive 3,7 (certainly in the case of 1 to 4) with very few exceptions, the absolute sign of ${ }^{n}{ }\left({ }^{199} \mathrm{Sn}^{117} \mathrm{Sn}\right)$ becomes available.

\begin{tabular}{|c|c|c|c|}
\hline $\begin{array}{l}\text { Fragment of } \\
\text { isotopomer }\end{array}$ & \multicolumn{2}{|c|}{ Experiment } & Coupling signs compared \\
\hline $\begin{array}{l}{ }^{1} \mathrm{H}-\mathrm{C}-{ }^{119} \mathrm{Sn}-\mathrm{E}-\mathrm{Sn} \\
{ }^{1} \mathrm{H}-\mathrm{C}-\mathrm{Sn}-\mathrm{E}-{ }^{119} \mathrm{Sn} \\
{ }^{1} \mathrm{H}-\mathrm{C}-{ }^{119} \mathrm{Sn}-\mathrm{E}-\mathrm{Sn} \\
{ }^{1} \mathrm{H}-\mathrm{C}-{ }^{119} \mathrm{Sn}-\mathrm{E}-{ }^{117} \mathrm{Sn}\end{array}$ & $\begin{array}{l}\text { A } \\
\text { B } \\
\text { C } \\
\text { D }\end{array}$ & $\begin{array}{l}\text { E/ }{ }^{1} \mathrm{H} \text { HETCOR } \\
\mathrm{E} /{ }^{1} \mathrm{H} \text { HETCOR } \\
{ }^{119} \mathrm{Sn} /{ }^{1} \mathrm{H} \text { HETCOR } \\
{ }^{119} \mathrm{~S} \mathrm{/} /{ }^{1} \mathrm{H} \text { HETCOR }\end{array}$ & $\begin{array}{l}{ }^{2} \mathrm{~K}\left({ }^{119} \mathrm{Sn}{ }^{1} \mathrm{H}\right) /^{1} \mathrm{~K}\left({ }^{119} \mathrm{SnE}\right) \\
{ }^{4} \mathrm{~K}\left({ }^{119} \mathrm{Sn}{ }^{1} \mathrm{H}\right) /^{1} \mathrm{~K}\left({ }^{119} \mathrm{SnE}\right) \\
{ }^{3} \mathrm{~K}\left(\mathrm{E}^{1} \mathrm{H}\right) /{ }^{1} \mathrm{~K}\left({ }^{119} \mathrm{SnE}\right) \\
{ }^{4} \mathrm{~K}\left({ }^{117} \mathrm{~S} n^{1} \mathrm{H}\right) /^{2} \mathrm{~K}\left({ }^{119} \mathrm{Sn}^{117} \mathrm{Sn}\right)\end{array}$ \\
\hline \multicolumn{4}{|c|}{ 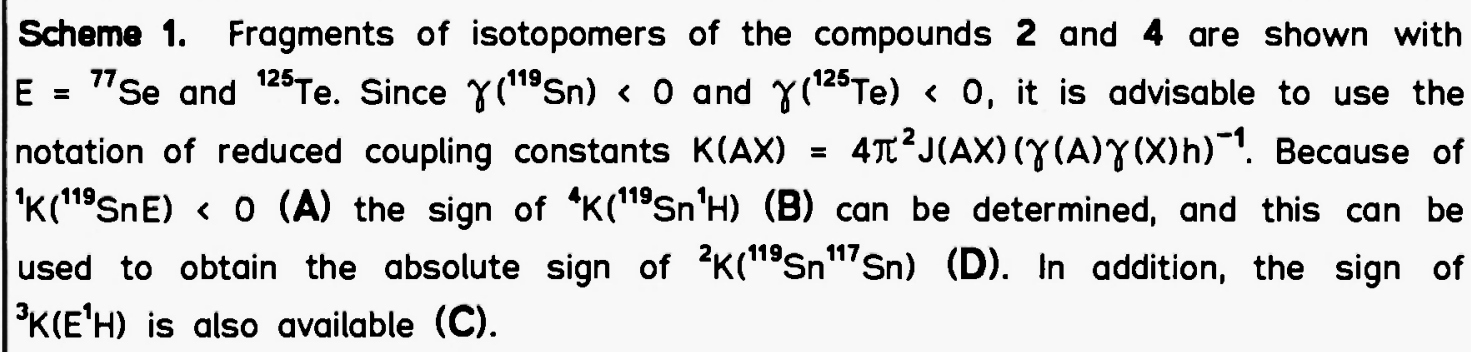 } \\
\hline
\end{tabular}


If the intervening atom happens to be a spin-1/2 nucleus such as ${ }^{77} \mathrm{Se}$ or ${ }^{125} \mathrm{Te}$, another method is also feasible, provided that there are small long-range coupling

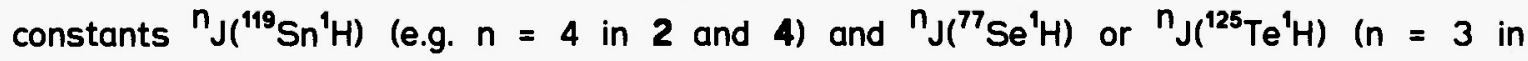
2 and 4). The strategy (Scheme 1) corresponds to that used for sign determination of ${ }^{2} \mathrm{~J}\left({ }^{119} \mathrm{SnN} \mathrm{N}^{117} \mathrm{Sn}\right)$ in tris(trimethylstannyl)amine ${ }^{10}$ when the magnetically active ${ }^{15} \mathrm{~N}$ nucleus served the same purpose as ${ }^{77} \mathrm{Se}$ or ${ }^{125} \mathrm{Te}$ in the present study. Relevant experiments are shown in Figures 1 and 2 and analogous experiments were also carried out for 3. The possibility of determining long-range coupling constants involving ${ }^{1} H$ which are not resolved in normal ${ }^{1} H$ NMR spectra from the 2D HETCOR experiments offers certain other advantages. These data can help to improve the measurement of ${ }^{77} \mathrm{Se}$ or ${ }^{125} \mathrm{Te}$ NMR spectra by application of the INEPT pulse sequence ${ }^{11}$ as has been shown in the case of ferrocene derivatives with organotin chalcogenide substituents ${ }^{12}$.

The negative sign of ${ }^{-} \mathrm{K}(\mathrm{SnSn})$ in $1,2,4$ and of ${ }^{2} \mathrm{~K}\left(S n^{13} \mathrm{C}\right)$ in 3 can be rationalized considering the sign dependence of geminal couplings on one-bond interactions and bond angles $^{13}$. If this dependence on the bond angle $\mathrm{SnESn}$ in bis(triorganotin)chalcogenides is significant, one expects a change in the sign of ${ }^{2} \mathrm{~K}\left(\mathrm{SnS}_{n}\right)$ for $E=0$ because bond angles SnOSn are frequently larger than $120^{\circ}$ (in contrast with $E=S, S e, T e$ ), and there are also examples of linear $S_{n} O S n$ arrangements for which $\left.\right|^{2} J\left(S_{n} O S_{n}\right) \mid$ can be as large as

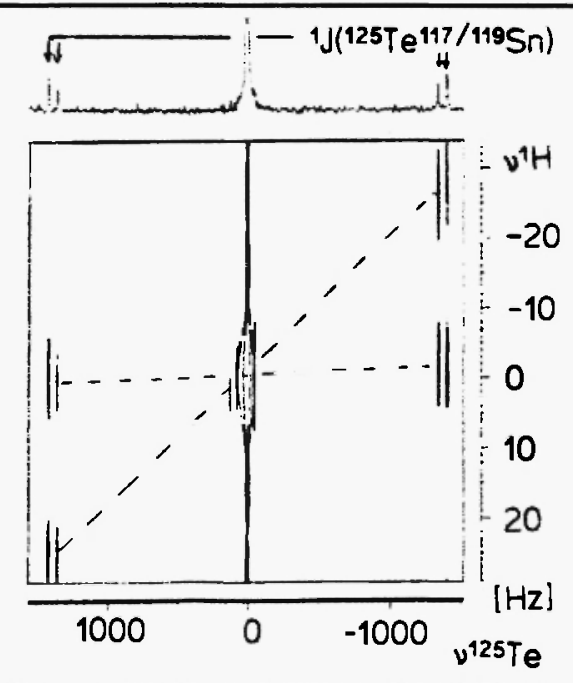

FIG 1. 157.6 MHz ${ }^{125} \mathrm{Te} /{ }^{1} \mathrm{H}$ HETCOR experiment of bis(trimethylstannyl)telluride (4) based on ${ }^{3} \mathrm{~J}\left({ }^{125} \mathrm{TeSnC}{ }^{1} \mathrm{H}\right.$ ) [spectral windows: $F_{2}=3500 \mathrm{~Hz}(2 \mathrm{~K})$ and $F_{1}=70 \mathrm{~Hz}$ (128 experiments of 128 transients each), zero-filling and Gaussian enhancement in both dimensions]. The positive tilt of all cross peaks for the ${ }^{117 / 119} \mathrm{Sn}$ satellites indicate that the signs of the pairs ${ }^{2} \mathrm{~K}\left({ }^{117 / 119} \mathrm{Sn}{ }^{1} \mathrm{H}\right)(<0) /{ }^{1} \mathrm{~K}\left({ }^{125} \mathrm{Te}^{117 / 119} \mathrm{Sn}\right)(<0)$ and ${ }^{4} \mathrm{~K}\left({ }^{117 / 119} \mathrm{SnTeSnC}{ }^{1} \mathrm{H}\right)(<0) /{ }^{1} \mathrm{~K}\left({ }^{125} \mathrm{Te}{ }^{117 / 149} \mathrm{Sn}\right)(<0)$ are all alike. 


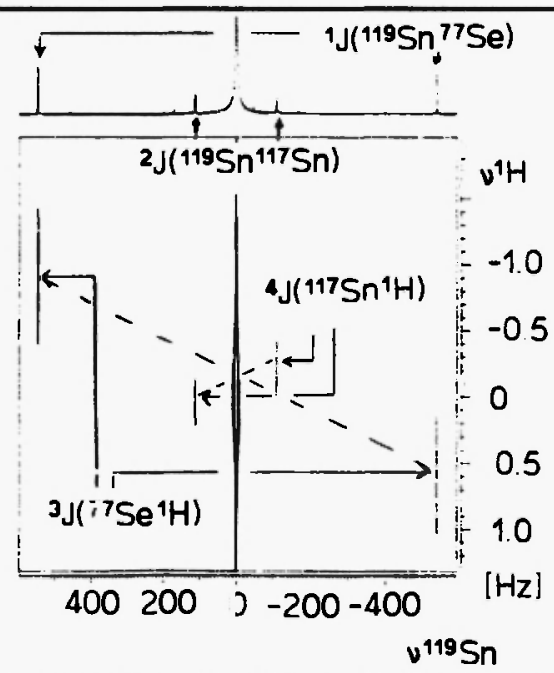

FIG 2. $186.5 \mathrm{MHz}{ }^{119} \mathrm{Sn} /{ }^{1} \mathrm{H}$ HETCOR experiment of bis(trimethylstannyl)selenide (2), based on ${ }^{2} \mathrm{~J}^{119} \mathrm{Sn}^{1} \mathrm{H}$ ) (spectral windows: $F_{2}=1500 \mathrm{~Hz}(4 \mathrm{~K})$ and $F_{1}=12 \mathrm{~Hz}$ (128 experiments of 8 transients each), zero-filling and Gaussian enhancement in both dimensions]. The negative tilt of the cross peaks for the ${ }^{77} \mathrm{Se}$ satellites indicate that ${ }^{1} \mathrm{~K}\left({ }^{119} \mathrm{Sn}^{77} \mathrm{Se}\right)(<0)$ and ${ }^{3} \mathrm{~K}\left({ }^{77} \mathrm{Se}^{1} \mathrm{H} \mathrm{SnMe}_{\mathrm{N}}\right.$ ( $>0$ ) are of opposite sign; the positive tilt of the cross peaks corresponding to the ${ }^{117} \mathrm{Sn}$ satellites prove that the signs of ${ }^{4} \mathrm{~K}\left({ }^{117} \mathrm{SnSeSnC} \mathrm{C}^{1} \mathrm{H}(<0)\right.$ and ${ }^{2} \mathrm{~K}\left({ }^{119} \mathrm{Sn}^{117} \mathrm{Sn}\right)(<0)$ are alike.

$1000 \mathrm{~Hz}^{14}$. Work in this direction is in progress. As for many other combinations of nuclei, the vicinal reduced coupling constants ${ }^{3} \mathrm{~K}\left(\mathrm{E}^{1} \mathrm{H}\right)\left(E={ }^{77} \mathrm{Se},{ }^{125} \mathrm{Te}\right.$ ) and ${ }^{3} \mathrm{~K}\left(\mathrm{Sn}^{1} \mathrm{H}\right)$ (in 3) are all positive. The sign of ${ }^{4} \mathrm{~K}\left({ }^{119} \mathrm{Sn}^{1} \mathrm{H}\right)$ is negative and this is also true for ${ }^{4} \mathrm{~K}\left({ }^{29} \mathrm{Si}^{1} \mathrm{H}\right)$ in 2(Si). However, the absolute values are very small, and the authors believe that a change in the sign of these parameters may readily take place.

\section{EXPERIMENTAL}

All samples were handled in an $\mathrm{N}_{2}$ atmosphere, observing all precautions to exclude traces of moisture and oxygen. The compounds $1^{15}, 2^{15}, 2(\mathrm{Si})^{16}, 3^{17}$ and $4^{15}$ were prepared following literature procedures.

NMR measurements were carried out using Bruker AC 300 Ipulse lengths for $90^{\circ}$ pulses: $\left.{ }^{1} \mathrm{H}(35 \mu \mathrm{s}),{ }^{13} \mathrm{C}(11 \mu \mathrm{s}),{ }^{29} \mathrm{Si}(12 \mu \mathrm{s}),{ }^{77} \mathrm{Se}(12 \mu \mathrm{s}),{ }^{125} \mathrm{Te}(13 \mu \mathrm{s}),{ }^{119} \mathrm{Sn}(14 \mu \mathrm{s})\right]$ and Bruker AM 500 lpulse length for $90^{\circ}$ pulses: ${ }^{1} H(11 \mu s),{ }^{13} \mathrm{C}(5.5 \mu s),{ }^{77} \mathrm{Se}(8 \mu \mathrm{s})$, $\left.{ }^{119} \mathrm{Sn}(7 \mu \mathrm{s}),{ }^{125} \mathrm{Te}(7 \mu \mathrm{s})\right]$ instruments, equipped with multinuclear units, for samples in $5 \mathrm{~mm}$ 0.d. tubes with $10-20 \%$ solutions in $C_{6} D_{6}$ at $26 \pm 1{ }^{\circ} \mathrm{C}$. Chemical shifts are given with respect to internal $\mathrm{Me}_{4} \mathrm{Si}\left(\delta^{1} \mathrm{H}\left(\mathrm{C}_{6} \mathrm{D}_{6}\right)=7.15 ; \delta^{13} \mathrm{C}\left(\mathrm{C}_{6} \mathrm{D}_{6}\right)=128.0 ; \delta^{29} \mathrm{Si}\right.$ with 
$\left.\Xi\left({ }^{29} \mathrm{Si}\right)=19.867184 \mathrm{MHz}\right), \mathrm{Me}_{2} \mathrm{Se}\left(\delta^{77} \mathrm{Se}\right.$ with $\left.\Xi\left({ }^{77} \mathrm{Se}\right)=19.071523 \mathrm{MHz}\right), \mathrm{Me}_{4} \mathrm{Sn}$

$\left(\delta^{119} \mathrm{Sn}\right.$ with $\left.\Xi\left({ }^{119} \mathrm{Sn}\right)=37.290665 \mathrm{MHz}\right)$ and $\mathrm{Me}_{2} \mathrm{Te}\left(\delta^{125} \mathrm{Te}\right.$ with $\Xi\left({ }^{125} \mathrm{Te}\right)=31.549802$

$\mathrm{MHz}$. $\Xi$ values were taken from Ref. 18.

\section{ACKNOWLEDGEMENT}

Support of this work by the Deutsche Forschungsgemeinschaft and the Fonds der Chemischen Industrie is gratefully acknowledged.

\section{REFERENCES}

1. J.D. Kennedy and W. McFarlane, Revs. Silicon, Germanium, Tin, Lead Compds. 1 (1974) 235-298. - (b) PJ Smith and A.P. Tupciauskas, Ann. Rep. NMR Spectrosc. 8 (1978) 291. - (c) B. Wrackmeyer, Annu. Rep. NMR Spectrosc. 16 (1985) 73-186.

2. (a) J.D. Kennedy and W. McFarlane, in J. Mason (ed.), Multinuclear NMR, Plenum Press, New York 1987, pp. 305-333.

3. W. McFarlane, J. Chem. Soc. (A) (1967) 528.

4. (a) J.D. Kennedy and W. McFarlane, J. Organomet. Chem. 94 (1975) 927. - (b) J.D. Kennedy and W. McFarlane, J. Chem. Soc. Dalton Trans. (1973) 2134.

5. W. McFarlane, Ann. Rep. NMR Spectrosc. 1 (1968) 135-168; 5 A (1972) 353-393.

6. C.J. Jameson, in J. Mason (ed.), Multinuclear NMR, Plenum Press, New York 1987, pp 89-131.

7. J.D. Kennedy and W. McFarlane, J.Chem.Soc. Chem.Commun. 1974, 983.

8. B. Wrackmeyer and G. Kehr, Z. Naturforsch., Teil B, 49 (1994) in the press.

9. (a) A. Bax and R. Freeman, J. Magn. Reson. 45 (1981). - (b) T.C. Wong, V. Rutar and J.S. Wang, J.Am.Chem.Soc. 106 (1984) 7046.

10. B. Wrackmeyer and H. Zhou, Magn.Reson.Chem. 28 (1990) 1066.

11. (a) G.A. Morris and R. Freeman, J.Am.Chem.Soc 101 (1979) 760. - (b) G.A. Morris, J.Am.Chem.Soc. 102 (1980) 428. - (c) D.P. Burum and R.R. Ernst, J. Magn. Reson. 39 (1980) 163.

12. M. Herberhold, M. Hübner and B. Wrackmeyer, Z. Naturforsch., Teil B, 48 (1993) 940.

13. C.J. Jameson, J. Am. Chem. Soc. 91 (1969) 6232.

14. S. Kerschl, B. Wrackmeyer, D. Männig, H. Nöth and R. Staudigl, Z. Naturforsch., Teil B, 42 (1987) 387.

15. F.W.B. Einstein, C.H.W. Jones, T. Jones and R.D. Sharma, Can. J. Chem. 61 (1983) 2611. 
16. M.R. Detty and M.D. Seidler, J. Org. Chem. 47 (1982) 1354.

17. E.W. Abel, B.C. Crosse and G.V. Hutson, J. Chem. Soc. (A) (1967) 2014.

18. J. Mason (ed.), Multinuclear NMR, Plenum Press, New York, 1987, pp 625-629.

Received: June 14, 1994 - Accepted: August 1, 1994 - Received in revised camera-ready form: September 14, 1994 
